\title{
ENTRE CAVALEIROS E PÍCAROS : LITERATURA E SOCIEDADE ESPANHOLA DA IDADE MÉDIA AO RENASCIMENTO
}

\author{
BETWEEN KNIGHTS AND PICAROS: LITERATURE AND \\ SPANISH SOCIETY FROM THE MIDDLE AGES TO THE \\ RENAISSANCE
}

Katia Aparecida da Silva Oliveira

Universidade Federal de Alfenas

\begin{abstract}
Resumo: A leitura da literatura espanhola do Medievo ao Renascimento revela um panorama literário e um vislumbre da realidade social e histórica do período. Notase que as representações de cavaleiros e, posteriormente, de pícaros, dialogam com valores e modelos de conduta social de quando foram criados ou (re)criados, contribuindo para a constituição de um quadro histórico e ampliando o olhar sobre o passado. Este artigo pretende analisar comparativamente personagens tidos como cavaleiros - El Cid e Amadís de Gaula observando como são revisitados em diferentes períodos e considerando as condições que propiciaram o surgimento de um personagem pícaro, oposto aos cavaleiros que até então povoavam o imaginário coletivo. Serão discutidas quatro obras: El Cantar de Mio Cid, Romancero Viejo, Amadís de Gaula e Lazarillo de Tormes, desenvolvendo um itinerário pela literatura espanhola do século XII ao XVI e observando como o tecido literário se relaciona com valores sociais de onde e quando surge.
\end{abstract}

Palavras-chave: Cavaleiro; Pícaro, Literatura e sociedade medieval.
Abstract: The reading of the Spanish literature of the Medieval period to the Renaissance discloses to a literary panorama and a glimpse of the social and historical reality of the period. One notices that the representations of knights and, later, picaros, dialogue with values and models of the social behavior of when they had been created or (re)created, contributing for the constitution of a historical picture and extending the look into the past. This article aims to analyze comparatively characters considered as knights - El Cid and Amadís de Gaula - observing as they are revisited in different periods and considering the conditions that had propitiated the picaro's character appearance, opposed to the knights who until then populated the collective imaginary. Four literary works will be argued: El Cantar de Mio Cid, Romancero Viejo, Amadís de Gaula and Lazarillo de Tormes, developing an itinerary through Spanish literature from the 12th to the 16th century and observing how the literary fabric relates to social values from where and when it arises.

Keywords: Knight; Picaro, Literature and medieval society. 
Se a literatura está intimamente relacionada ao povo de que se origina, não seria um engano pensar que o estudo de seus heróis e anti-heróis permitiria reconhecer valores e características da vida desse mesmo povo em diferentes momentos de sua história. Nesse sentido, percorrendo a literatura dos séculos XII a XVI produzida na Península Ibérica, especialmente no território da atual Espanha, observa-se a construção de personagens que carregam consigo uma série de aspectos que os identificam com o sistema social e ideológico de uma época repleta de conflitos, contradições e mudanças.

Partindo desse raciocínio, a análise comparativa de uma série desses personagens, como a que se propõe aqui, busca realçar elementos que os compõem e que são recuperados e/ou adaptados em diferentes obras da literatura, sempre estabelecendo um diálogo com o meio sócio-histórico de onde surgem. Recuperando personagens de obras de diferentes momentos temporais, pode-se perceber os diversos processos de transformação do homem, que tem na literatura o registro de uma perspectiva de sua história.

Como esse trabalho se enquadra nas fronteiras entre os estudos literários e os estudos historiográficos, optou-se por adotar como objeto de estudo obras literárias de origem castelhana que apresentam personagens significativos para o imaginário coletivo da época. A análise de cada personagem, de forma individual ou comparada estará pautada em trabalhos tanto da teoria e crítica literárias, como também do âmbito historiográfico.

O primeiro grande herói da tradição literária castelhana, El Cid, surge em uma obra da qual se tem um manuscrito conservado do início do século XIII, embora haja relatos relacionados a essa história escritos por cronistas anteriores a essa época. O Cantar de Mio Cid $^{1}$ recupera a história do cavaleiro castelhano Rodrigo Díaz de Vivar (10431099), conhecido, como diz García de Cortázar, como "un gran caudillo militar, típico hombre de guerra - fiel observante del código feudal"2. Tendo atuado em diversas batalhas, Rodrigo Díaz de Vivar é conhecido principalmente por ter reconquistado o reino de Valência do poder dos mouros e aí governado até o fim de sua vida.

Como obra literária, o Cantar de Mio Cid é composto em forma de verso, formando uma epopeia que, descendente da tradição clássica, é adaptada ao momento,

\footnotetext{
${ }^{1}$ ANONIMO. Cantar de Mio Cid. Versión de Pedro Salinas. Barcelona: Plaza \& Janés, 1997.

${ }^{2}$ GARCÍA DE CORTÁZAR, José Angel. Historia de España Alfaguara II, La época medieval. Madrid: Alianza, 1976, p. 162.
}

\section{5}


seguindo a tradição das canções de gesta. Quanto ao conteúdo, a obra tem seu enredo desenvolvido no período da Reconquista, que se estende do século XI ao XVI, e é composta por conflitos políticos, culturais e bélicos, os quais protagonizaram um processo de retomada de territórios ocupados por povos muçulmanos na Península Ibérica. García de Cortázar comenta que nesse momento

[...] la ocupación de territorios enemigos se hace, alternativamente, a través de una colonización pacífica y unos enfrentamientos bélicos, a los que el naciente ideal de cruzada, producto de una Iglesia reestructurada y combativa, proporciona una justificación de combate por la fe. Junto a ese criterio ideológico la Reconquista parece apoyarse más - como se percibe claramente ya en el círculo palatino de Alfonso III de Asturias y, poco después, coincidiendo con el establecimiento de la dinastía Jimena en Navarra - en el de recuperación de un territorio para restaurar en él un dominio político legítimo, el heredado de los reyes godos, sentimiento en el que tanto Cataluña como Castilla participan mucho más tardíamente y siempre como algo secundario. ${ }^{3}$

O movimento de tomada de terras, promovido a partir de diferentes estratégias bélicas e políticas revelam uma complexa rede de relações entre povos. Assim, se por um lado Carlos Fuentes ${ }^{4}$ comenta que "A Reconquista foi, antes de tudo, um acontecimento militar. Sobre o fulcro da guerra, muitas coisas sobreviveram ou foram criadas, modelando o perfil da Espanha [...]", sugerindo que nesse momento, a partir de diferentes eventos bélicos, foram moldados sistemas sociais e de valores que contribuíram para a configuração desse país. Por outro, deve-se também considerar a Idade Média na Península Ibérica como um momento de profundas transformações, contatos e convivências entre culturas de origem cristã, muçulmana e judaica, majoritariamente. Nesse sentido, María de la Concepción Piñero Valverde ${ }^{5}$ menciona que "embora não fossem cordiais, tampouco eram agressivas as relações entre os três grupos", evidenciando um contexto de trocas e de interinfluência entre culturas. De qualquer

\footnotetext{
${ }^{3}$ Ibid. p. 154.

${ }^{4}$ FUENTES, Carlos. O espelho enterrado: reflexões sobre a Espanha e o novo mundo. Trad. Mauro Gama. Rio de Janeiro: Rocco, 2001, p. 60.

${ }^{5}$ PIÑERO VALVERDE. María de la Concepción. Terra de fronteiras: a Espanha do século XI ao XIII. In: MONGELLI, Lênia Márcia (coord.). Mudanças e rumos: o Ocidente medieval (séculos XI-XIII). Cotia, SP: Íbis, 1997, p. 149-184. Página citada159.
} 
maneira, a singularidade e as contradições do período contribuíram para a estruturação política e ideológica do reino castelhano, refletindo-se na sua literatura do momento.

Há de se considerar que a literatura, como forma de expressão artística, não deixaria de refletir a complexidade e contradições da época em que surge. A inspiração histórica do herói, no caso de Mio Cid, associa história e literatura, demonstrando como já dizia Ricoeur ${ }^{6}$, que a natureza narrativa presente nos âmbitos literário e historiográfico os aproxima. Considerando que a historiografia se constrói a partir de um discurso narrativo, construído com a intenção de revelar a versão de seu autor sobre o que relata, não seria um absurdo crer que entre o discurso narrativo literário e o discurso narrativo historiográfico poderia haver cruzamentos, sobreposições e permeabilidade.

Tratando mais especificamente da literatura medieval, vale recordar que não havia naquele momento um grande distanciamento entre o que era considerado literatura ou história, podendo o texto literário ser lido ou entendido como historiográfico. A natureza ficcional que poderia estar presente nas obras da época se misturava a relatos históricos, permitindo a possibilidade de ser lida como verídica por seus primeiros leitores, mas eventualmente causando dificuldades para a interpretação do leitor moderno que tente distinguir ficção de relatos sobre o passado.

A natureza dessas obras permite que sejam interpretadas, considerando a proposta de Le Goff $^{7}$ de que há construções textuais que podem ser entendidas como documentos/monumentos, ou seja, como fontes para o estudo histórico e, ao mesmo tempo, representações de sua época, imagens das organizações políticas e ideológicas das quais são fruto. No caso do Cantar, nota-se o cuidado com a verossimilhança e o empenho em preservar, como comenta Piñero Valverde ${ }^{8}$, a apresentação de personagens históricos e o registro de dados reais na narrativa, destacando a relação da obra ficcional com a história.

El Cid é um personagem de profundo significado nesse período histórico, encarnando uma série de valores que comporiam um ideal de homem castelhano. Tal ideal, constituído por valores como a honra, a lealdade ao rei e a coragem, manteve-se

\footnotetext{
${ }^{6}$ RICOEUR, Paul. A memória, a história, o esquecimento. Trad. Alain François (et al). Campinas, SP: Editora da Unicamp, 2007.

${ }^{7}$ LE GOFF, Jacques. História e Memória. Campinas: Editora UNICAMP, 2003, p. 525-541.

${ }^{8}$ PIÑERO VALVERDE. María de la Concepción. Terra de fronteiras: a Espanha do século XI ao XIII. In: MONGELLI, Lênia Márcia (coord.). Mudanças e rumos: o Ocidente medieval (séculos XI-XIII). Cotia, SP: Íbis, 1997, p. 149-184. Página citada 175.
} 
vivo no imaginário coletivo daqueles que habitavam os territórios do Reino de Castela e outros próximos a ele durante séculos, fundamentado um sistema identitário profundamente vinculado à preservação de uma ordem social feudal.

Dessa forma, El Cid pode ser interpretado como um arquétipo masculino que representa o homem ideal dentro de um sistema social que se desenvolve em meio a um contexto de estabelecimento de uma política de preservação do poder feudal e de difusão e exaltação de valores sociais e religiosos, fundamentados especialmente na ideia de honra, coragem e fidelidade ao rei e à Igreja. É possível considerar que a obra, assim, assume um tom propagandístico importante para a consolidação e manutenção dos reinos cristãos medievais.

Como cavaleiro, El Cid pode ser compreendido como um representante das ordens de cavalaria, importantes no período medieval pelo papel militar que desenvolviam. Essas ordens eram formadas por "hermandades de caballeros de dedicación a la vez militar y religiosa, las cuales, como las huestes señoriales y las milicias concejiles, mantenían dentro del ejército su independencia como cuerpos armados autónomos" e atuavam como uma espécie de corpo de soldados com o qual os monarcas ou outros senhores poderiam contar.

De forma geral, pode-se dizer que sendo um cantar de gesta - uma épica medieval -, a obra herda aspectos da épica clássica, constituindo uma história que representa a fundação ou legado de um povo, contando com um herói que sintetiza a essência do que o determina como tal. Sendo uma epopeia, a obra castelhana pode ser compreendida como um espaço de propaganda ideológica:

[...] la épica puede entenderse como el arte de la propaganda de la clase dominante feudal, arte de origen germánico y desarrollado, precisamente, entre pueblos con tales raíces, como es el caso de Castilla. Es tan obvia la relación épica-propaganda-clase dominante-héroe, que el género ejemplifica de modo paradigmático el hecho de que las ideas dominantes en una época determinada sean las de la clase entonces dominante. ${ }^{10}$

\footnotetext{
${ }^{9}$ GARCÍA DE CORTÁZAR, José Angel. Historia de España Alfaguara II, La época medieval. Madrid: Alianza, 1976, p. 169.

${ }^{10}$ BLANCO AGUINAGA, Carlos; RODRÍGUEZ PUÉRTOLAS Julio; ZAVALA, Iris M. Historia social de la literatura española (en lengua castellana), Vol I. Madrid: Akal, 2000. p. 62.
}

\section{8}


O caráter estático da sociedade medieval, representado pela ideia de que "cada hombre nace en una determinada situación social y su papel consiste en vivir de acuerdo con ella; de este modo no sólo contribuirá al bien común, sino que salvará su alma y llegará al Reino de los Cielos, no menos jerarquizado que el de este mundo." 11 se reproduz durante toda a narrativa. El Cid representa socialmente o grupo dos fidalgos, normalmente pequenos proprietários de terras, sem muito prestígio entre outros grupos da alta nobreza nesse momento. Mas, por mais que seu protagonismo na obra pareça anunciar uma proposta de transformação social (vale recordar que Rodrigo Díaz de Vivar é injustamente desterrado na narrativa e atua após o desterro como um guerreiro conquistador), o que se percebe na obra é a manutenção da realidade feudal, com o herói demonstrando veementemente sua lealdade ao rei e seu desejo de reincorporação à corte castelhana. Como cavaleiro, ele personifica um homem adequado para aquela realidade social, honrado, admirado e invejado, uma figura que simboliza a vida sob um sistema senhorial. Já nos primeiros versos preservados da obra o personagem é descrito dessa maneira:
De los sos ojos
tan fuertemientre llorando,
tornava la cabeça i estávalos catando.
Vío puertas abiertas e uços sin cañados,
alcándaras vázias sin pielles e sin mantos,
e sin falcones e sin adtores mudados.
Sospiró mio Çid ca mucho avie grandes cuidados.
Fabló mio Çid bien e tan mesurado:
"grado a tí, señor padre, que estás en alto!
Esto me an buelto mios enemigos malos." 12

A cena que representa o sofrimento de $E l C i d$ frente ao desterro injusto e à perda do estilo de vida que tinha até então, constrói a imagem de um homem que embora se

\footnotetext{
${ }^{11}$ Ibid., p. 53.

${ }^{12}$ ANONIMO. Cantar de Mio Cid. Versión de Pedro Salinas. Barcelona: Plaza \& Janés, 1997, p. 70

Versão em castelhano moderno de Pedro Salinas:

Los ojos de Mío Cid mucho llanto van llorando

hacia atrás vuelve la vista y se quedaba mirándolos.

Vio cómo estaban las puertas abiertas y sin candados,

vacías quedan las perchas sin mantos,

sin halcones de cazar y sin azores mudados.

Suspira el Cid porque va de pesadumbre cargado.

$Y$ habló, como siempre habla, tan justo y tan mesurado:

"Bendito seas Dios mío, Padre que está en lo alto"

Contra mi tramaron esto mis enemigos malvados." (disponível na edição citada)
} 
destaque por suas atitudes e convicções, também padece. Esse homem modelar que vai sendo apresentado sem muitos detalhes no decorrer da narrativa é também humano, aproximando-se de quem tem contato com sua história. De forma engenhosa vão sendo inseridos em meio à ação narrativa aspectos da composição do personagem, construindoo aos poucos e transformando suas ações em parte dos elementos que o compõem.

Por outro lado, o caráter pouco descritivo da obra, que atende às necessidades da oralidade e da construção de um universo cavaleiresco cheio de ação, não omite a caracterização de um herói que atende às especificidades da vida de um cavaleiro medieval que caçava com falcões, entre outras atividades comuns aos membros dos grupos da cavalaria, que era justo e moderado, ainda que em uma situação de injustiça como a que se encontrava.

Assim, a narrativa cheia de eventos conflitivos do Cantar é elaborada a partir de um realismo que, associado a aspectos históricos, estabelece a verossimilhança e permite a identificação do leitor com o herói, que se apresenta humano como ele. Nos versos citados já se percebe que $E l$ Cid é um herói que, diferentemente daqueles da épica clássica, representa sua humanidade com lágrimas aos olhos sofrendo com o desterro e com a desonra, aproximando-se do homem comum que poderia conhecer a sua história tanto na época medieval como depois dela. Piñero Valverde comenta que no Cantar

O cuidado com a verossimilhança estende-se a certos traços psicológicos. É o que se percebe na delicada caracterização íntima das figuras que, longe de idealizadas, revelam sua humanidade, feita de força, de fraqueza e de sentimentos que se chocam. Perpassa todo o Poema o conflito entre a lealdade devida pelo Cid a Alfonso VI de Castela, de quem era vassalo, e sua mágoa pela injusta punição que o rei lhe infligira. Mas não faltam episódios em que a humanidade do protagonista é colhida em momentos de ternura e mesmo aparente fraqueza. ${ }^{13}$

Essa humanidade que, como diz Piñero Valverde, ressurge na obra em diferentes momentos, é ressaltada e acaba se transformando em um mecanismo que conquista a empatia do público em relação ao herói, propiciando sua inserção no imaginário coletivo

\footnotetext{
${ }^{13}$ PIÑERO VALVERDE. María de la Concepción. Terra de fronteiras: a Espanha do século XI ao XIII. In: MONGELLI, Lênia Márcia (coord.). Mudanças e rumos: o Ocidente medieval (séculos XI-XIII). Cotia, SP: Íbis, 1997, p. 149-184. Página citada 176.
} 
e garantindo a sua sobrevivência na oralidade a ponto de ter sua história recontada e reconstruída em outros gêneros literários como, por exemplo, o romance.

Dessa forma, pode-se dizer que no decorrer de alguns séculos a propaganda da épica convive com fim da Reconquista e o estabelecimento do Império castelhano, tendo seu herói revisitado e adaptado ao início do pensamento renascentista. Nesse sentido, no Romancero viejo ${ }^{14}$, composto por romances ${ }^{15}$ registrados entre os séculos XV e XVI, mas provavelmente de origem anterior, encontram-se, junto a relatos relacionados a temáticas amorosas, cotidianas e históricas, narrativas que tratam das aventuras de heróis de tradição clássica, histórica e cavaleiresca - como é o caso de El Cid.

Nesses poemas, a tradição heroica difundida por $\mathrm{El} \mathrm{Cid}$ surge em poemas que aludem a passagens das narrativas épicas, influenciando, ademais, a construção de outros heróis. Observa-se que os romances não se afastam totalmente das histórias originais a que se referem, mas apresentam protagonistas ambientados à realidade do fim da Idade Média, um pouco mais individualistas e questionadores que os do período anterior. A influência do pensamento humanista começa a se projetar nessa poética popular, ressaltando um tipo de herói menos centrado no coletivo, como ocorre na épica, e mais focado em suas próprias impressões:

\section{Cabalga Diego Laínez}

al buen rey besar la mano

consigo se los llevaba

los trescientos hijosdalgo,

entre ellos iba Rodrigo,

el soberbio castellano.

Todos cabalgaban a mula,

sólo Rodrigo a caballo.

Todos visten oro y seda,

Rodrigo va bien armado, $[. . .]^{16}$

\footnotetext{
${ }^{14}$ ANONIMO. Romancero. Edición de Alejandro González Segura. Madrid: Alianza, 2008.

${ }^{15}$ Os romances são poemas típicos da cultura espanhola medieval, difundidos originalmente por meio da tradição oral. Acredita-se que têm influência de épicas clássicas e de cantares de gesta, dos quais retirariam trechos que seriam adaptados a essa forma poética.Têm natureza narrativa e formalmente pode-se dizer que são formados por versos heptassílabos (segundo a tradição de contagem métrica portuguesa e octossílabos, segundo a tradição espanhola) com rima toante nos versos pares.

${ }^{16}$ ANONIMO. Romancero. Edición de Alejandro González Segura. Madrid: Alianza, 2008, p. 224.

Trecho de Romance del Cid Ruy Díaz
} 


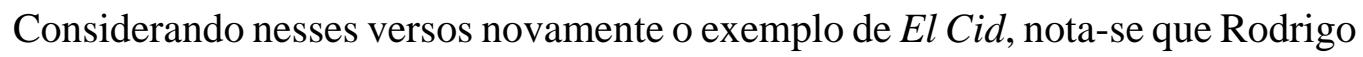
ressurge como um cavaleiro que se destaca entre os demais, reforçando a ideia de sua individualidade em relação ao grupo. Nos romances o personagem assume um ar soberbo, mais heroico, talvez, chegando inclusive a ser um crítico do rei, mas não do sistema político e social em que vivia. Nota-se que arquétipo do herói se transforma e, no caso de El Cid, como representante de uma identidade castelhana, percebe-se que assume um perfil um pouco distante daquele do cantar de gesta, mas não a ponto de ser irreconhecível em relação ao personagem medieval: nos romances ele não demonstra suas fraquezas e, embora ainda preserve o tom realista, é menos humano e mais idealizado, mais próximo de uma perfeição heroica.

\section{- ¡Oh Valencia, oh Valencia,} de mal fuego seas quemada!

Primero fuiste de moros que de cristianos ganada.

Si la lanza no me miente, a moros será tornada; aquel perro de aquel Cid prenderelo por la barba, su mujer, doña Jimena, será de mí cautivada, su hija, Urraca Hernando, será mi enamorada, después de yo harto de ella la entregaré a mi compañía. $[. . .]^{17}$

Nesses versos El Cid se transforma em um cavaleiro odiado por seus inimigos, notadamente os mouros, uma vez que com a finalização da Reconquista e com a construção ideológica que se difundiu, esses poderiam ser considerados ainda inimigos dos cavaleiros cristãos. O desejo de vingança do rei mouro Búcar em relação ao Cid pela conquista de Valência se concretizaria por meio dos atos contra o herói que seu rival pretendia cometer: desde prendê-lo pela barba - uma afronta direta à honra de um cavaleiro - à prisão da esposa e amancebamento com a filha. Nesses termos, com a honra em perigo, resta ao cavaleiro agir:

\footnotetext{
${ }^{17}$ Ibid., p. 241.
}

Trecho de Romance de Búcar sobre Valencia 


\section{[...] Estando el moro embarcado, el buen Cid que llegó al agua, y por ver al moro en salvo, de tristeza reventaba; mas con la furia que tiene, una lanza le arrojaba, y dijo: - arrecogedme esa lanza, que quizás tiempo vendrá que os será bien demandada. ${ }^{18}$}

O heroísmo de $E l$ Cid correndo atrás de seu inimigo e sua frustração ao perdê-lo em um barco em um rio não faz com que desista, regalando ao rei mouro uma lança para que no futuro possam se enfrentar. A impiedade do herói se mostra como algo de sua natureza não só nesse, como também em outros poemas, quando, por exemplo, decapita um inimigo ${ }^{19}$ sem hesitar.

O realismo que existia no Cantar ainda sobrevive nos romances, como uma característica literária que permite a analogia entre o narrado e o cotidiano. Além disso, por mais que nesse momento o herói dos romances conviva com os heróis dos Livros de Cavalaria, obras cujas histórias se tornam muito populares na Península Ibérica, especialmente a partir do século XV, o universo fantasioso em que estão circunscritos não contamina os versos populares.

Por outro lado, não seria totalmente equivocado dizer que sua composição é influenciada pelos heróis desse tipo de histórias. Numa época de incertezas, no fim da Idade Média, quando o Reino de Castela já tem suas raízes e a propaganda promovida pela épica começa a perder forças, as histórias de heróis superiores ao homem comum surgem como uma opção para sobreviver aos questionamentos e conflitos que despontavam.

A Espanha que se constrói como uma potência no fim do século XV e início do XVI vivencia uma série de crises econômicas, políticas e sociais. Desde crises para a sucessão monárquica, à miséria popular e eventos de grande impacto como o fím da Reconquista e a Conquista da América, observa-se um ambiente repleto de ideias contraditórias. É nesse meio que ganham força representações literárias idealizadas de

\footnotetext{
${ }^{18}$ ANONIMO. Romancero. Edición de Alejandro González Segura. Madrid: Alianza, 2008, p. 243. Trecho de Romance de Búcar sobre Valencia

${ }^{19}$ A cena ocorre no poema Romance del Cid Ruy Días, presente em: ANÓNIMO, Romancero. Barcelona: Orbis, 1982, p. 67.
} 
heróis cavaleiros e o mundo em que habitam, como uma forma de distanciamento da realidade difícil.

Johan Huizinga ${ }^{20}$ diz que "O culto dos heróis no fim da Idade Média encontra sua forma literária na biografia do cavaleiro perfeito", afinal, seja a partir das narrativas do Romancero, ainda fortemente realistas, seja a partir das fantásticas histórias dos Livros de Cavalarias, a construção literária de cavaleiros nobres, perfeitos, honrados e corajosos, permite um distanciamento da realidade cotidiana e um mergulho na fantasia.

No âmbito da literatura castelhana, os Livros de Cavalaria são parte de uma tradição frutífera em outras culturas, como a francesa ou a bretã. Fizeram bastante sucesso as histórias de cavalaria relacionadas a Carlos Magno ou ao chamado ciclo bretão, que já existiam desde, pelo menos, o século XII, mas foi somente no século XV que uma obra desse tipo, o Amadís de Gaula ${ }^{21}$, de Garci Rodríguez de Montalvo, é produzida na Espanha. Tentando delimitar esse tipo de narrativa, pode-se dizer que para González:

A novela de cavalaria terá como base a evocação de um passado de aventuras próprio da épica, centrado em heróis modelares - que se tornam um tipo repetido até a exaustão -, porém transformado pelo refinamento próprio da corte; nesse refinamento há um especial destaque para o sentimento amoroso, centrado na mulher, vista à luz da doutrina do amor cortês. ${ }^{22}$

Poder-se-ia pensar que os Livros de Cavalarias conformariam uma versão da épica adaptada a outro contexto histórico, filosófico e social. O Humanismo que se desenvolvia a fins da Idade Média, conjugado com uma realidade herdeira de um contexto bélico relacionado à Reconquista e à Conquista da América, que dava notícia de terras desconhecidas repletas de seres, plantas ou grupos humanos até então desconhecidos, alimentavam a imaginação e propiciavam o surgimento de histórias cheias de elementos maravilhosos.

\footnotetext{
${ }^{20}$ HUIZINGA, Johan. O outono da Idade Média. Trad, Francis Petra Janssen. São Paulo: Cosac Naify, 2013, p. 107.

${ }^{21}$ RODRÍGUEZ DE MONTALVO, Garci. Amadís de Gaula I -II. Edición de Juan Manuel Cacho Blecua. Madrid: Cátedra, 2008.

${ }^{22}$ GONZÁLEZ, Mario M. O Amadís de Gaula e as novelas de cavalaria. In: Leituras de Literatura Espanhola (da Idade Média ao século XVII). São Paulo: Letraviva; FAPESP, 2010, p. 210-227. Página citada 212.
} 
O caso de Amadís, conhecido também como Donzel del Mar - por haver sido abandonado no mar -, revela um personagem que desde o nascimento demonstra ser superior. Sua beleza destacada desde a mais tenra infância, conjugada com a valentia e honradez típicas de um cavaleiro marcam sua trajetória que se completa ao conhecer a jovem donzela Oriana, que se transforma na senhora de sua alma (en días de su vida no fue enojado de la servir y en ella su coraçón fue siempre otorgado, y este amor turó quanto ellos turaron, que assí como la él amava assí amava ella a él, en tal guisa que una hora nunca de amar se dexaron ${ }^{23}$ ), aquela para a qual dedica sua existência e busca alcançar virtudes suficientes para ser digno de ter a seu lado.

O momento em que decide, ainda muito jovem, que deve ser sagrado cavaleiro demonstra sua natureza pura e corajosa:

- Señor, si a vos pluguiesse, tempo sería de ser yo cavallero.

El Rey dixo:

- ¡Cómo, Donzel del Mar!, ¿os esforçáis para mantener caballería? Sabed que es ligero de aver y grave de mantener. Y quien este nombre de caballería ganar quisiere y mantenerlo en su honra, tantas e tan graves son las cosas que ha de fazer, que muchas vezes se le enoja el coraçón, y si tal caballero es que por miedo o codicia dexa de hazer lo que conviene, más le valdría la muerte que en vergüença vivir, y por ende ternía por bien que por algún tiempo os sufráis.

El Donzel del Mar le dixo:

- Ni por todo esso no dexaré yo de ser caballero, que si en mi pensamiento no tuviesse de cumplir esso que avéis dicho, no se esforçaría mi coraçón para lo ser. Y pues a la vuestra merced soy criado, complid en esto comigo lo que debéis; si no, buscaré otro que lo faga. ${ }^{24}$

O herói que se firma na imagem de Amadís de Gaula é imbuído de valores essenciais ao universo cavaleiresco: a coragem, a honra, a capacidade de vencer as adversidades e de se manter fiel ao propósito da cavalaria, formam um personagem que além de tudo sabe o que quer e busca realizar o que considera correto.

Recorde-se que o maravilhoso povoa os Livros de Cavalaria, evocando um universo onde tudo é possível. Povoadas por elementos de culturas e lendas antigas,

\footnotetext{
${ }^{23}$ RODRÍGUEZ DE MONTALVO, Garci. Amadís de Gaula I. Edición de Juan Manuel Cacho Blecua. Madrid: Cátedra, 2008, p. 269.

${ }^{24}$ Ibid., p. 270.
} 
aliados a costumes do momento e inspiradas pelas novidades trazidas das terras americanas, essas obras se distanciam da realidade de crise permitindo que a fantasia tomasse os leitores e ao mesmo tempo, mantivessem vivos alguns ideais de conduta que caíam em desuso.

Os cavaleiros são, dessa maneira, protagonistas de histórias compostas por elementos fantásticos que, por mais que preservem aspectos da vida medieval, distanciam-se dela pela falta de realismo. É frequente também perceber que as histórias de tais cavaleiros adotam modelos estabelecidos, fazendo dessas histórias obras que seguem um modelo narrativo comum que havia sido popularizado. Pode-se, inclusive, dizer que esses heróis

[...] reiteram habitualmente um percurso narrativo que já vemos em Amadís de Gaula: o nascimento clandestino de Amadís; seu abandono às águas protegido por sinais que o identifiquem; o seu resgate, adoção e educação; a investidura como cavaleiro; o posterior reconhecimento e a conseguinte aquisição de linhagem em função da qual e para a qual ele irá desenvolver suas aventuras, em diante. ${ }^{25}$

A fórmula usada estruturalmente nos Livros de Cavalaria permitiu que suas histórias se fixassem na memória de quem as conhecia, tornando-se parte da tradição oral, reproduzindo-se e atualizando-se a partir dela. Como comenta Megale ${ }^{26}$, considerandose que naquela época a leitura de textos escritos era algo a que poucos tinham acesso, pode-se crer que "muito maior público atingia a leitura indireta, auditiva: um leitor, em voz alta, podia ter a ouvi-lo numeroso público. [...] Esse público de um leitor ou leitores que se sucediam, ora mais, ora menos numeroso, abria uma via de transmissão puramente oral”. Assim, por meio dessa forma de transmissão a partir da oralidade, as histórias de cavalaria contadas e recontadas diversas vezes, podiam ser adaptadas e contar com infinitas continuações criadas pelos seus amantes, mas sem nunca deixar de preservar a natureza cavaleiresca e modelar de seus heróis.

De forma geral, esses heróis compartilham boa parte das qualidades e valores de El Cid na épica ou dos romances, porém são mais idealizados e adaptados a um mundo

${ }^{25}$ GONZÁLEZ, Mario M. O Amadís de Gaula e as novelas de cavalaria. In: Leituras de Literatura Espanhola (da Idade Média ao século XVII). São Paulo: Letraviva; FAPESP, 2010, p. 210-227. Página citada 221.

${ }^{26}$ MEGALE, Heitor. A Demanda do Santo Graal: das origens ao Códice Português. São Paulo: FAPESP; Ateliê Editorial, 2001, p. 30. 
distante daquele do herói castelhano, além de serem integrados a uma concepção de cavalaria literariamente trabalhada:

Como ideal de vida bela, a concepção cavaleiresca tem aspectos peculiares. É um ideal essencialmente estético, feito de fantasias coloridas e sentimentos elevados, que também almeja ser um ideal de ético: o pensamento medieval só pode conferir nobreza a um ideal de vida se o puder vincular à piedade e à virtude. Nessa sua função ética, o ideal cavaleiresco fica sempre a dever, estorvado por sua origem pecaminosa. Pois o cerne do ideal é sempre orgulho elevado à condição de beleza. [...] Do orgulho, estilizado e exaltado, nasce a honra, que é o centro da vida nobre. ${ }^{27}$

Se o orgulho está no cerne da construção do herói de cavalaria, promovendo sua individualidade e favorecendo a vida nobre, pode-se pensar que diferente do arquétipo formado por El Cid (especialmente na épica) que representa o homem castelhano, num sentido que abarca um coletivo identitário, o herói de cavalaria representa o indivíduo que se destaca do coletivo e representa a individualidade. Díaz Plaja ${ }^{28}$ chega a comentar: “¿qué es, por ejemplo, la novela de aventuras, sino el afán de representar a un héroe arquetípico (fiel a una misión colectiva) al personaje típico, atento únicamente a la rúbrica de sus proezas?".

$\mathrm{O}$ arquétipo do herói vai se adaptando à nova realidade do fim da Idade Média, persistindo no imaginário coletivo como uma figura modelar masculina. Esse herói, que já não é tão realista e próximo dos leitores, ainda reúne em si o necessário para dar vida aos valores que embora estivessem em desuso, em meio a uma crise que fatalmente traria transformações, tentam sobreviver em sua figura.

Os Livros de Cavalaria contavam, assim, com protagonistas que reuniam características de um herói idealizado, mas individualizado, capaz até de, eventualmente, se equivocar. Tal herói representa as contradições do Renascimento, a valorização do homem e sua distinção do coletivo. Por outro lado, não chega a questionar o sistema social e político estabelecido, a pesar de tudo. Nota-se que essas obras agregam pensamentos e valores contraditórios, imprimindo artisticamente um retrato do momento:

${ }^{27}$ HUIZINGA, Johan. O outono da Idade Média. Trad, Francis Petra Janssen. São Paulo: Cosac Naify, 2013, p. 99.

${ }^{28}$ DÍAZ PLAJA, Guillermo. España en su literatura. Madrid: Alianza, 1969, p. 55.

\section{7}


Quer dizer, a literatura cavaleiresca é local de diálogo entre o ideal (fraternidade, paz) e o real (rivalidade, guerra), o coletivo (cavalaria) e o individual (cavaleiro), a fidelidade às normas (Percival, Galaad) e a fidelidade ao sentimento (Lancelote, Tristão), a tradição (realismo) e a inovação (nominalismo) filosóficas, um mundo decrépito (o reino de Artur) e um mundo renovado (o reino do Graal). ${ }^{29}$

Outro aspecto que se deve levar em consideração ao pensar nos Livros de Cavalaria é o fato de que muitas vezes eram compreendidos como verdadeiros, como parte da história. A ideia de veracidade promovida nesse tipo de narrativa, assim como ocorrera com o Cantar de Mio Cid ou com o Romancero, embora nessas obras realmente existisse um diálogo com eventos históricos, permitia que suas histórias se reproduzissem, da mesma forma que as anteriores, no imaginário coletivo e que ganhassem a empatia do público, ao observar nelas um tipo de herói com o qual gostaria de se identificar.

O pensamento de individualidade típico do Renascimento que já se observa nos Livros de Cavalaria pode ser percebido de forma mais desenvolvida em obras que questionam a realidade e o sistema social e político em que se vivia. Em meio à crise social e política instaurada no reino de Castela no século XVI, surgem na literatura relatos que denunciam e criticam o estilo de vida que era promovido então.

Aproximadamente entre 1552-1554, surge um pequeno romance, de autoria anônima, denominado Lazarillo de Tormes ${ }^{30}$, que inaugura o gênero literário que hoje conhecemos como picaresca ou romance picaresco. Essa obra, de forma astuta, desconstrói a imagem de herói que vinha sendo cultivada e adota um anti-herói como protagonista.

Para tanto, a obra teve de se apresentar como um relato real, assumindo a forma de uma carta, gênero que estava em moda, e se apresentando como uma autobiografia gênero que mantêm um forte vínculo a ideia de "verdade". O anonimato do autor compactua com essas estratégias relacionadas à forma - o formato epistolar e autobiográfico - garantindo ao texto uma aura de verdade e, ao mesmo tempo, conferindo

\footnotetext{
${ }^{29}$ FRANCO JÚNIOR, Hilário. Deum circulum, cujus centrum est ubique, circumferentia nusquam: a Távola redonda, síntese da utopia cavaleiresca. In: MONGELLI, Lênia Márcia. E fizerom taes maravilhas... Histórias de cavaleiros e cavalarias. São Paulo: Ateliê, 2012, p. 17-38. Página citada 22.

${ }^{30}$ ANONIMO. Lazarillo de Tormes. Edición de Francisco Rico. Madrid: Cátedra, 2002.
}

\section{8}


uma seriedade adornada de comicidade a uma obra que atacava pontualmente alguns grupos e práticas sociais.

Lázaro de Tormes é um pícaro, o oposto dos cavaleiros das obras anteriores, um anti-herói forjado em um momento de crise social e econômica, no qual os ideais propagados por cavaleiros como $\mathrm{El} \mathrm{Cid} \mathrm{perdem} \mathrm{o} \mathrm{sentido.} \mathrm{Criado} \mathrm{como} \mathrm{um} \mathrm{personagem}$ advindo de um grupo social distante da nobreza, pobre e sem recursos, em uma sociedade sem qualquer possibilidade de mobilidade social, Lázaro usa diversas artimanhas para sobreviver, nem sempre lícitas:

[...] o pícaro prescinde do trabalho. Uma primeira opção será a de se tornar criado de algum senhor que não trabalha e ostenta o luxo de ser servido. Mas, para subir, o pícaro começa por romper com seu lugar de origem e com os valores que ele possa significar. Com isso, o pícaro é uma primeira manifestação de individualismo, que se traduz na procura de um espaço próprio [...] o pícaro opta por caminhos vedados pela sociedade estamental, numa atitude libertária que a choca, pois significa a opção pelo vício. ${ }^{31}$

De forma geral, esse tipo de romance pode ser lido como paródia à literatura cavaleiresca, revelando uma realidade muito distante dos ideais promovidos por obras desse tipo. As primeiras palavras do prólogo já demonstram a ironia que comporá o texto: "Yo por bien tengo que cosas tan señaladas, y por ventura nunca oídas ni vistas, vengan a noticia de muchos y no se entierren en la sepultura del olvido, pues podría ser que alguno que las lea halle algo que le agrade, y a los que no ahondaren tanto los deleite." 32. Nota-se que início do prólogo do Lazarillo parece anunciar um dos tantos Livros de Cavalaria que faziam sucesso naquele momento. "Histórias nunca ouvidas e nem vistas" são parte da vida dos cavaleiros andantes de histórias como a de Amadís de Gaula, porém, ao seguir com a leitura da história de Lázaro de Tormes, o leitor do século XVI se dá conta de que o que tem em mãos é uma narrativa de eventos mais que conhecidos do seu cotidiano, repleta de personagens que poderiam existir em seu círculo social e de situações que provavelmente presenciou.

\footnotetext{
${ }^{31}$ GONZÁLEZ, Mario M. A saga do anti-herói: Estudo sobre o romance picaresco espanhol e algumas de suas correspondências na literatura brasileira. São Paulo: Nova Alexandria, 1994, p. 70.

${ }^{32}$ ANONIMO. Lazarillo de Tormes. Edición de Francisco Rico. Madrid: Cátedra, 2002, p. 3.
} 
A história de Lázaro é a história de um miserável, de alguém que tenta sobreviver e, quem sabe, ascender um pouquinho socialmente. A novidade de sua narrativa é o fato de que esse tipo de história não era parte da tradição literária, não era suficientemente notável para ser representada. O cotidiano ou alguém com uma vida tão marginal não compunham os temas do cânone literário de até então. A provocação que já se anuncia no prólogo "podría ser que alguno que las lea halle algo que le agrade, y a los que no ahondaren tanto los deleite", indica que a leitura superficial da obra pode ser divertida, mas uma leitura aprofundada provavelmente não levará ao deleite, ou seja, o que se encontrará nessa obra não é o deleite que se encontrava nas histórias fantasiosas de cavaleiros, mas uma realidade crua e dura, difícil de aceitar.

A paródia de histórias de cavaleiros é retomada em diversas partes da história de Lázaro, não deixando o leitor se esquecer da diferença dessa narrativa para outras que conhecia. Esse jogo é percebido, por exemplo, no início do Primeiro Tratado do romance:

Mi nacimiento fue dentro del río Tormes, por la cual tomé el sobrenombre; y fue desta manera: mi padre, que Dios perdone, tenía cargo de proveer una molienda de una aceña que está ribera de aquel río, en la cual fue molinero más de quince años; y estando mi madre una noche en la aceña, preñada de mí, tomóle el parto y parióme allí. De manera que con verdad me puedo decir nascido en el río. ${ }^{33}$

A forma como se apresenta o nascimento de Lázaro evoca o nascimento de cavaleiros andantes, mas a nobreza da cavalaria nada tem a ver com o nascimento do filho de um moleiro às margens de um rio. A vida de Lázaro, sua pobreza, sua fome e falta de origem nobre, nada tem da cavalaria, a natureza do personagem não poderia ser mais distinta daquela preconizada para os heróis da épica, dos romances ou dos Livros de Cavalaria. Lázaro mente, tem vícios, rouba e sempre sofre com a fome, é o oposto dos heróis, é um pícaro que, de seu lugar marginal, consegue olhar para as injustiças de sua realidade a partir do lugar de quem é explorado.

De forma geral, o individualismo do pícaro permite que construa um olhar distanciado e crítico sobre sua realidade, denunciando a hipocrisia e os vícios daqueles grupos que estão no poder e demonstrando as dificuldades e formas de sobreviver ao

\footnotetext{
${ }^{33}$ ANONIMO. Lazarillo de Tormes. Edición de Francisco Rico. Madrid: Cátedra, 2002, p. 12
} 
sistema que lhe era imposto. A literatura que se faz nesse momento é fruto e reflexo da realidade. A construção do pícaro como personagem é uma forma de dar representatividade a diversos tipos que conviviam nesse meio e que nada tinham em comum com o modelo arquetípico do cavaleiro, que deixava de ter sentido nesse momento de decadência.

Refazendo o percurso da Idade Média ao Renascimento, nota-se que durante a Reconquista, quando o império castelhano ainda estava se estabelecendo, a literatura assume um papel propagandístico contando com um herói realista, El Cid, arquetípico e capaz de representar a imagem do castelhano ideal. Esse modelo arquetípico se reproduz nos romances de tradição oral, mas cada vez mais idealizado. Com o fortalecimento do império, com a conquista da América e com a propagação do pensamento renascentista, a ideia de cavaleiro é revista, fortalecida e distanciada da realidade, situando-se em um universo fantástico com histórias menos comprometidas com o cotidiano, buscando levar o leitor ao deleite, sem, contudo, deixar de contribuir para a manutenção do sistema feudal. Esse modelo de cavaleiro diferencia-se do modelo da épica por estar mais centrado em si mesmo, sendo mais individualista e menos ligado ao bem-estar e manutenção do coletivo.

Finalmente, com a decadência do sistema político e econômico de Castela no século XVI, a literatura dá forma ao pícaro, exemplo de anti-herói, completamente oposto ao cavaleiro medieval. Esse pícaro que parodia as histórias cavaleirescas, posiciona-se criticamente frente à sua sociedade, denunciando-a e demonstrando a fragilidade dos modelos de cavaleiro idealizado numa realidade frágil e em crise.

A partir desse itinerário de leitura por algumas importantes obras da literatura castelhana, o qual poderia incluir diversas outras obras, é possível verificar que a relação da literatura com o meio onde é criada é intrínseca e que a construção de personagens modelares ou não, representam uma série de valores internalizados culturalmente e que se multiplicam a partir da memória coletiva. A obra literária, nesse sentido, não pode deixar de ser vista como um documento/monumento ${ }^{34}$ capaz de discutir e preservar o passado de forma elaborada, sem abrir mão de uma composição estética que torna o seu alcance atemporal.

\footnotetext{
${ }^{34}$ LE GOFF, Jacques. História e Memória. Campinas: Editora UNICAMP, 2003.
}

\section{1}


Revista Signum, 2017, vol. 18, n. 1.

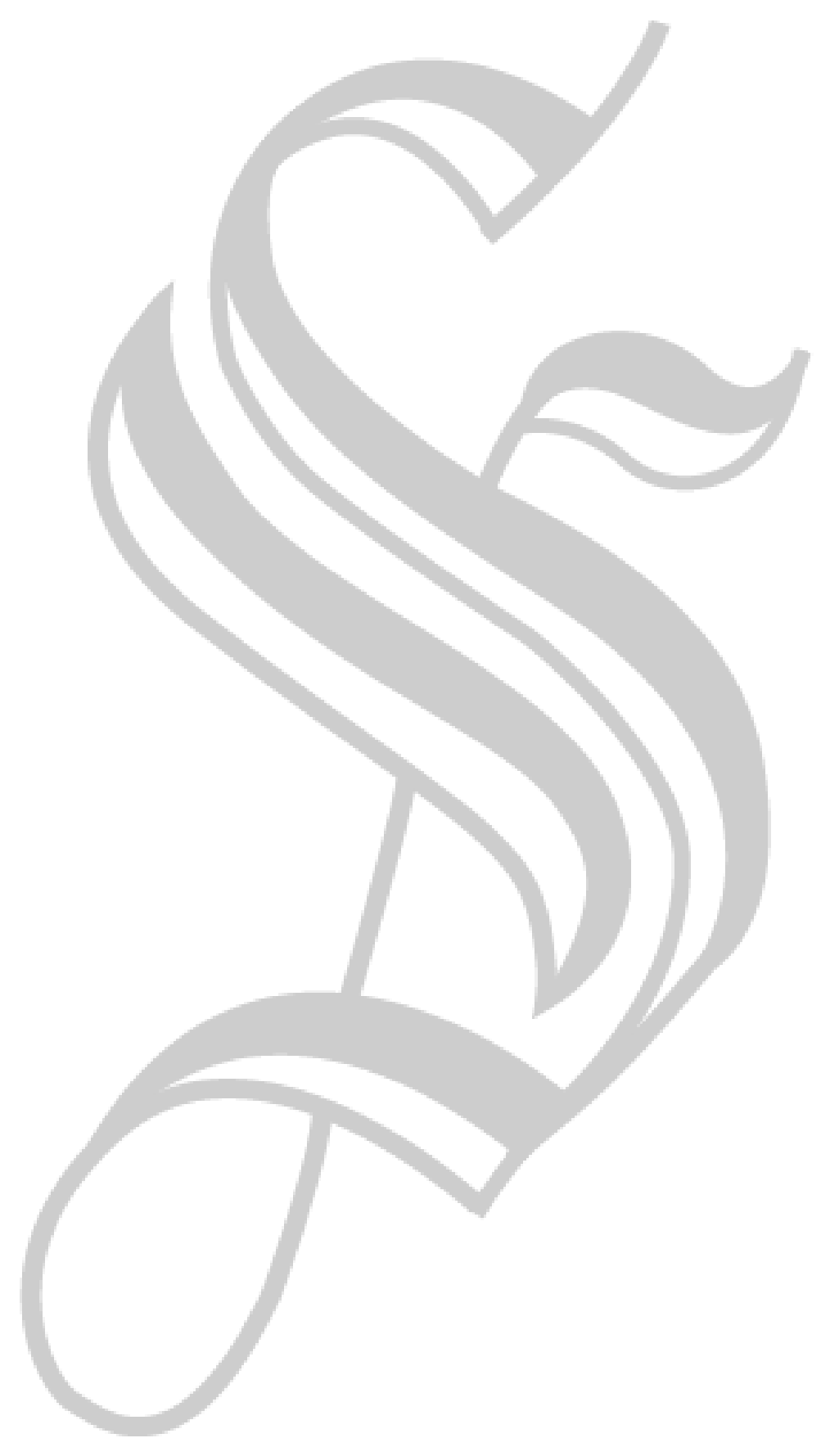

122 